\title{
Front Matter: Volume 7422
}

, "Front Matter: Volume 7422," Proc. SPIE 7422, Ninth International Conference on Solid State Lighting, 742201 (14 September 2009); doi: 10.1117/12.846229

SPIE Event: SPIE Optical Engineering + Applications, 2009, San Diego, California, SPIE. United States 


\title{
PROCEEDINGS OF SPIE
}

\section{Ninth International Conference on Solid State Lighting}

\author{
Ian T. Ferguson \\ Christoph Hoelen \\ Jianzhong Jiao \\ Tsunemasa Taguchi \\ Editors
}

3-5 August 2009

San Diego, California, United States

Sponsored and Published by

SPIE 
The papers included in this volume were part of the technical conference cited on the cover and title page. Papers were selected and subject to review by the editors and conference program committee. Some conference presentations may not be available for publication. The papers published in these proceedings reflect the work and thoughts of the authors and are published herein as submitted. The publisher is not responsible for the validity of the information or for any outcomes resulting from reliance thereon.

Please use the following format to cite material from this book:

Author(s), "Title of Paper," in Ninth International Conference on Solid State Lighting, edited by lan T. Ferguson, Christoph Hoelen, Jianzhong Jiao, Tsunemasa Taguchi, Proceedings of SPIE Vol. 7422 (SPIE, Bellingham, WA, 2009) Article CID Number.

ISSN 0277-786X

ISBN 9780819477125

Published by

SPIE

P.O. Box 10, Bellingham, Washington 98227-0010 USA

Telephone +1 3606763290 (Pacific Time) · Fax +1 3606471445

SPIE.org

Copyright (C) 2009, Society of Photo-Optical Instrumentation Engineers

Copying of material in this book for internal or personal use, or for the internal or personal use of specific clients, beyond the fair use provisions granted by the U.S. Copyright Law is authorized by SPIE subject to payment of copying fees. The Transactional Reporting Service base fee for this volume is $\$ 18.00$ per article (or portion thereof), which should be paid directly to the Copyright Clearance Center (CCC), 222 Rosewood Drive, Danvers, MA 01923. Payment may also be made electronically through CCC Online at copyright.com. Other copying for republication, resale, advertising or promotion, or any form of systematic or multiple reproduction of any material in this book is prohibited except with permission in writing from the publisher. The CCC fee code is 0277-786X/09/ $\$ 18.00$.

Printed in the United States of America.

Publication of record for individual papers is online in the SPIE Digital Library.

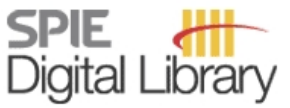

SPIEDigitalLibrary.org

Paper Numbering: Proceedings of SPIE follow an e-First publication model, with papers published first online and then in print and on CD-ROM. Papers are published as they are submitted and meet publication criteria. A unique, consistent, permanent citation identifier (CID) number is assigned to each article at the time of the first publication. Utilization of CIDs allows articles to be fully citable as soon they are published online, and connects the same identifier to all online, print, and electronic versions of the publication. SPIE uses a six-digit CID article numbering system in which:

- The first four digits correspond to the SPIE volume number.

- The last two digits indicate publication order within the volume using a Base 36 numbering system employing both numerals and letters. These two-number sets start with 00, 01, 02, 03, 04, $05,06,07,08,09,0 A, 0 B \ldots 0 Z$, followed by 10-1Z, 20-2Z, etc.

The CID number appears on each page of the manuscript. The complete citation is used on the first page, and an abbreviated version on subsequent pages. Numbers in the index correspond to the last two digits of the six-digit CID number. 


\section{Contents}

vii Conference Committee

\section{GROWTH I}

742203 The effect of $\mathbf{M g}$ and Si impurities on the optical property of InGaN-light emitting diode (Invited Paper) [7422-02]

E.-H. Park, Kyung Hee Univ. (Korea, Republic of) and S-Light, Co., Ltd. (Korea, Republic of);

J. Jang, Kyung Hee Univ. (Korea, Republic of)

742204 Green LED development in polar and non-polar growth orientation (Invited Paper) [7422-03]

C. Wetzel, M. Zhu, Y. Li, W. Hou, L. Zhao, W. Zhao, S. You, C. Stark, Y. Xia, M. DiBiccari,

T. Detchprohm, Rensselaer Polytechnic Institute (United States)

\section{ALTERNATIVE DESIGN}

742206 The design of a spectrally tunable light source (Invited Paper) [7422-05]

K. J. Dowling, B. Kolsky, Philips Color Kinetics (United States)

742208 Practical method for measurement of AC-driven LEDs at a given junction temperature by using active heat sinks [7422-07]

Y. Zong, National Institute of Standards and Technology (United States); P.-T. Chou, M.-T. Lin, Industrial Technology Research Institute (Taiwan); Y. Ohno, National Institute of Standards and Technology (United States)

742209 Developing an accelerated life test method for LED drivers [7422-08]

L. Han, N. Narendran, Rensselaer Polytechnic Institute (United States)

SOLID STATE LIGHTING AND OLEDS PLENARY SESSION: JOINT SESSION WITH CONFERENCE 7415

$7422 \mathrm{OB}$ Recent progress and future prospect of high-performance near-UV based white LEDs: from ECO lighting to medical application (Plenary Paper) [7422-10]

T. Taguchi, Yamaguchi Univ. (Japan)

\section{PHOSPHORS}

7422 OE Phosphor quenching in LED packages: measurements, mechanisms, and paths forward (Invited Paper) [7422-13]

A. A. Setlur, J. J. Shiang, GE Global Research (United States); M. E. Hannah, U. Happek, Univ. of Georgia (United States) 
$7422 \mathrm{OH} \quad$ Extensive analysis of the degradation of phosphor-converted LEDs [7422-16] M. Meneghini, L.-R. Trevisanello, F. de Zuani, N. Trivellin, G. Meneghesso, E. Zanoni, Univ. of Padova (Italy)

\section{GROWTH II}

7422 OJ III-nitride epilayers on $\mathrm{ZnO}$ Substrates by $\mathrm{MOCVD}$ using $\mathrm{Al}_{2} \mathrm{O}_{3}$ as a transition layer [7422-18] N. Li, W. Fenwick, A. Melton, Georgia Institute of Technology (United States); I.-H. Hung, Z. C. Feng, National Taiwan Univ. (Taiwan); C. Summers, M. Jamil, I. Ferguson, Georgia Institute of Technology (United States)

7422 OK Nanoscale InGaN/GaN on ZnO substrate for LED applications [7422-19]

I.-H. Hung, Y.-R. Lan, T. H. Wu, Z. C. Feng, National Taiwan Univ. (Taiwan); N. Li, H. Yu, I. Ferguson, Georgia Institute of Technology (United States); W. Lu, Fisk Univ. (United States)

7422 OL Method for controlling light emission of LEDs [7422-20]

H.-Y. Chou, T.-H. Yang, National Central Univ. (Taiwan)

$74220 \mathrm{M} \quad$ Low temperature buffer growth for the development of vertical light emitting diodes [7422-21]

R. W. Nicholas, R. W. Losher, F. H. Zhao, S. P. Glenn, M. H. Kane, Univ. of Oklahoma (United States)

\section{GROWTH III}

7422 OP MOCVD growth of $\mathbf{G a N}$ on Si substrates using an ALD-grown $\mathrm{Al}_{2} \mathrm{O}_{3}$ interlayer [7422-24] W. Fenwick, A. Melton, N. Li, T. Xu, C. Summers, M. Jamil, I. Ferguson, Georgia Institute of Technology (United States)

$74220 Q \quad$ Optical properties and material studies of InGaN/GaN multi-quantum well light emitting diode wafers with different structures [7422-25]

T. W. Kuo, T. Y. Lin, Z. C. Feng, National Taiwan Univ. (Taiwan); W. Liu, S. J. Chua, Institute of Materials Research and Engineering (Singapore); H. L. Tsai, J. R. Yang, National Taiwan Univ. (Taiwan); Y. S. Huang, National Taiwan Univ. of Science and Technology (Taiwan);

I. Ferguson, Georgia Institute of Technology (United States); W. Lu, Fisk Univ. (United States)

\section{APPLICATION I}

7422 OT LED solution for E14 candle lamp [7422-43]

Y. Li, Y. Liu, Philips Lighting (China); E. P. Boonekamp, Philips Lighting (Netherlands); L. Shi, Y. Mei, T. Jiang, Q. Guo, H. Wu, Philips Lighting (China)

7422 OV Understanding heat transfer mechanisms in recessed LED luminaires [7422-30]

T. Dong, N. Narendran, Rensselaer Polytechnic Institute (United States) 
7422 0X SSL technology development and commercialization in the global context (Invited Paper) [7422-32]

K. L. Simons, S. W. Sanderson, Rensselaer Polytechnic Institute (United States)

$74220 Z$ An active lighting module with natural light guiding system and solid state source for indoor illumination [7422-34]

C.-A. Chen, Y.-Y. Chen, A. J.-W. Whang, National Taiwan Univ. of Science and Technology (Taiwan)

742211 Design a programmable Fresnel lens and arrange LED sources to optimize the illuminance and uniformity of a medium or large LED-based lighting system with varied shapes [7422-36] W.-G. Chen, Yung Ta Institute of Technology \& Commerce (Taiwan)

742212 Color rendering ability and luminous efficacy enhancements in white light-emitting diodes [7422-44]

R. Mirhosseini, M. Schubert, S. Chhajed, J. Cho, J. K. Kim, E. F. Schubert, Rensselaer

Polytechnic Institute (United States)

\section{POSTER SESSION}

742215 Investigation of illumination efficiency on the LED therapy with different array types [7422-39] H.-C. Chen, National Yunlin Univ. of Science and Technology (Taiwan); C.-J. Liou, De Lin Institute of Technology (Taiwan)

742216 The influence of Si doping to the characteristics of AIGaAs / AlAs distributed Bragg reflectors [7422-40]

C.-H. Tu, Yuan Ze Univ. (Taiwan) and Visual Photonics Epitaxy Co., Ltd. (Taiwan); N.-P. Chen, Yuan Ze Univ. (Taiwan); J.-H. Liu, Visual Photonics Epitaxy Co., Ltd. (Taiwan)

742217 Resonant acoustic calorimetry of the interaction of high-power laser radiation with crystals [7422-41]

A. V. Konyashkin, Institute of Radio-engineering and Electronics (Russian Federation) and NTO IRE-Polus (Russian Federation) and Moscow Institute of Physics and Technology (Russian Federation); V. A. Tyrtyshnyy, Moscow Institute of Physics and Technology (Russian Federation); A. V. Doronkin, D. V. Myasnikov, NTO IRE-Polus (Russian Federation) and Moscow Institute of Physics and Technology (Russian Federation); O. A. Ryabushkin, Institute of Radio-engineering and Electronics (Russian Federation) and NTO IRE-Polus (Russian Federation) and Moscow Institute of Physics and Technology (Russian Federation)

742218 Optical and structural properties of InN grown by HPCVD [7422-42]

M. Buegler, M. Alevli, R. Atalay, G. Durkaya, I. Senevirathna, Georgia State Univ. (United States); M. Jamil, I. Ferguson, Georgia Institute of Technology (United States); N. Dietz, Georgia State Univ. (United States)

Author Index 
Downloaded From: https://www.spiedigitallibrary.org/conference-proceedings-of-spie on 26 Apr 2023

Terms of Use: https://www.spiedigitallibrary.org/terms-of-use 


\title{
Conference Committee
}

\author{
Conference Chairs
}

Ian T. Ferguson, The University of North Carolina at Charlotte (United States)

Christoph Hoelen, Philips Lighting B.V. (Netherlands)

Jianzhong Jiao, OSRAM Opto Semiconductors Inc. (United States)

Tsunemasa Taguchi, Yamaguchi University (Japan)

Program Track Chair

Ian T. Ferguson, Georgia Institute of Technology (United States)

Program Committee

Srinath K. Aanegola, GE Lumination LLC (United States)

Andrew A. Allerman, Sandia National Laboratories (United States)

Ian E. Ashdown, byHeart Consultants Ltd. (Canada)

Lianghui Chen, Institute of Semiconductors (China)

Volker K. Härle, OSRAM Opto Semiconductors GmbH (Germany)

Matthew H. Kane, University of Oklahoma (United States)

Asif $\mathbf{M}$. Khan, University of South Carolina (United States)

Michael R. Krames, Philips Lumileds Lighting Co. (United States)

Yung-Sheng Liu, National Tsing Hua University (Taiwan)

Eun-Hyun Park, Kyung Hee University (Korea, Republic of)

Seong-Ju Park, Gwangju Institute of Science and Technology (Korea, Republic of)

Robert V. Steele, Strategies Unlimited (United States)

Chih-Chung Yang, National Taiwan University (Taiwan)

\section{Session Chairs}

1 Growth I

Jianzhong Jiao, OSRAM Opto Semiconductors Inc. (United States)

2 Alternative Design

Chih-Chung Yang, National Taiwan University (Taiwan)

3 Solid State Lighting and OLEDs Plenary Session: Joint Session with Conference 7415

Ian T. Ferguson, The University of North Carolina at Charlotte (United States)

Franky So, University of Florida (United States) 
4 OLEDs and Solid State Lighting: Joint Session with Conference 7415

Ian T. Ferguson, The University of North Carolina at Charlotte (United States)

5 Phosphors

Tsunemasa Taguchi, Yamaguchi University (Japan)

6 Growth II

Hugo J. Cornelissen, Philips Research Nederland B.V. (Netherlands)

$7 \quad$ Growth III

Edward D. Petrow, Lincoln Technical Services, Inc. (United States)

8 Application I

Nikolaus Dietz, Georgia State University (United States)

9 Application II

Ian T. Ferguson, The University of North Carolina at Charlotte (United States) 